\title{
STUDIES OF ANTI-EMETIC DRUGS:
}

A COMPARATIVE STUDY OF CYCLIZINE. (MARZINE ${ }^{\circledR}$ ), PIPAMAZINE (MORNIDINE $\left.{ }^{\circledR}\right)$, TRIMETḦOBENZAMIDE

(TIGAN $\left.{ }^{\circledR}\right)$, AND HYOSCINE

\section{Ellen Blatchford, M.B.*}

Anything which can alleviate the unpleasant and uncomfortable complication of vomiting during the postoperative period warrants the most arduous and careful investigation. While it would seem that anti-emetic drugs have been covered adequately in the literature of anaesthetic and general medical journals, it was felt that there is always an extra appreciation of their action by first-hand knowledge. In this study we have compared the anti-emetic value of cyclizine lactate (Marzine $\left.{ }^{\circledR}\right)$, pipamazine (Mornidine ${ }^{\circledR}$ ), trimethdbenzamide hydrochloride $\left(\right.$ Tigan $\left.^{\circledR}\right)$, and hyoscine.

Cyclizine lactate (Marzine $\left.{ }^{\circledR}\right)$ is a white crystaline solid, with the formula<smiles>CN1CCN(C=C=O)CC1</smiles>

It has both an atropine-like and an antihistaminic action. It depresses the parasympathetic, thus blocking a fall in blood-pressure which can result from stimulation of the vagus.

Pipamazine (Mornidine ${ }^{\circledR}$ ) is a phenothiazine derivative, being a tranquilizer with a separation of the anti-emetic and tranquilizing qualities. Its action is on the medullary chemoreceptor centre. Its formula is:

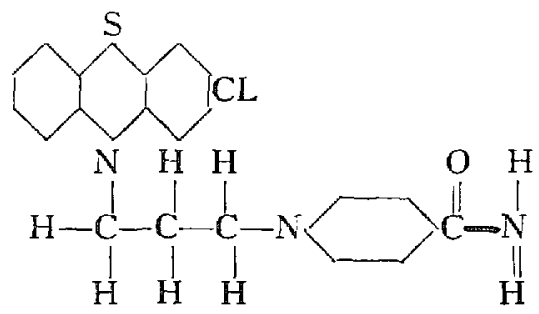

Trimethobenzamide hydrochloride (Tigan $\left.{ }^{\circledR}\right)^{\prime}$ is a substituted benzamide with the following formula:

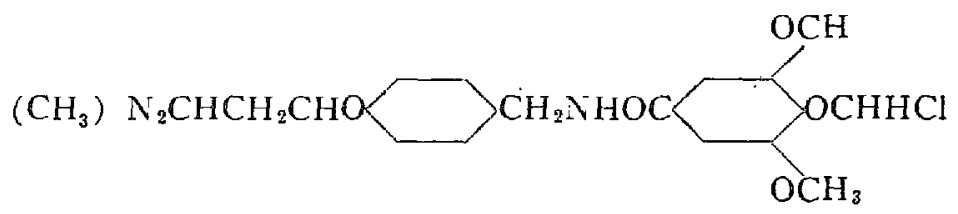

Its action is on the "trigger zone" in the medulla without accompanying sedative, toxic, or cardiorespiratory depressant effects.

*Department of Anaesthesia, Women's College Hospital, Toronto.

Can. Anaes. Soc. J., vol. 8, no. 2, March, 1961. 
Hyoscine is an old and well known drug, and is noted for its cortical depressant action, drying effect, and amnesic properties. Waters in 1938 looked upon hyoscine as a useful cardiovascular antagonist to the effect of morphine, and used it to counteract the depressant effects of pre-anaesthetic sedation.

\section{INVESTIGATION}

In this series of cases each drug was used for a period of one week, and with the introduction of a control week when no anti-emetic was given, the method of administration formed a five-week cycle. The anti-emetic of the week was ordered with the preoperative sedation (Demerol and atropine), and the antiemetic was repeated in the recovery room filteen minutes after arrival. The dosage was as follows:

Cyclizine lactate (Marzine ${ }^{\circledR}$ )

$50 \mathrm{mg}$. one hour preoperatively with sedation

$50 \mathrm{mg}$. fifteen minutes after arrival in the recovery room

Pipamazine (Mornidine ${ }^{\circledR}$ )

first series $\quad 5 \mathrm{mg}$. with preoperative sedation

$5 \mathrm{mg}$. in the recovery room

second series $5 \mathrm{mg}$. with preoperative sedation

$2.5 \mathrm{mg}$. in the recovery room

Trimethobenzamide hydrochloride (Tigan ${ }^{(2)}$ )

first series $\quad 100 \mathrm{mg}$. with preoperative sedation

$100 \mathrm{mg}$. in the recovery room

second series $200 \mathrm{mg}$. with preoperative sedation

$200 \mathrm{mg}$. in the recovery room

Hyoscine

gr. 1/100 to $1 / 200$ with preoperative sedation

All the drugs were given intramuscularly.

The patients were observed carefully and any vomiting occurring in the recovery room was charted. Nausea, although noted at the time and recorded, was not considered in the analysis, since it was felt that the positive observation of vomiting was a more reliable factor. All patients were visited on the wards and their reactions during the next twenty-four hours were recorded. A total of 781 patients were observed.

The operative procedures involved in this series of cases ranged from major abdominal work to the usual type of minor operations. In order to test the distribution in each anti-emetic group and in the control group, the operations were classified into major and minor, and the former further subdivided into head and neck, abdominal, and vaginal. There was no significant difference in the distribution ( $P$ being .90 ).

Since it has been noted by Dent et al. ${ }^{1}$ and Roberts ${ }^{2}$ that the type of ariaesthetic can be closely associated with postoperative vomiting, it was decided to examine the incidence of volatile anaesthetics and cyclopropane used as against nitrous oxide and thiopentone. The distribution was not statistically significant on comparing the five groups, $\mathrm{P}$ being .70 , making the groups sufficiently similar 
so that straightforward comparisons could be made with the results observed. It is interesting to note that Belleville, Bross, and Howland ${ }^{3}$ found in their investigation that intra-abdominal surgery produced a higher incidence of vomiting. They believe that the experience of the anaesthetist is a factor in producing nausea and vomiting and that light levels of anesthesia produce less vomiting.

It will have been noticed that two series were conducted with pipamazine and with trimethobenzamide. It was found that some very sharp falls in blood pressure occurred in the recovery room when a $5 \mathrm{mg}$.-dese of pipamazine was administered; consequently, after three weeks observation, it was decided to halve the dose postoperatively to see if this complication could be avoided. In the second series the dose of trimethobenzamide was doubled, since experience and further information indicated that $100 \mathrm{mg}$. was too little.

\section{Results}

TABLE I

A Comparison of the InCIDENCE of VoMíting Between Cyclizine and Control Groups

\begin{tabular}{|c|c|c|c|}
\hline & No vomiting & Vomiting & Total \\
\hline \multicolumn{4}{|l|}{ Controls } \\
\hline $\begin{array}{l}\text { observed value } \\
\text { expected value }\end{array}$ & $\begin{array}{l}75.00 \\
87.69 \\
1.836\end{array}$ & $\begin{array}{l}68.00 \\
55.31 \\
2.911\end{array}$ & $\begin{array}{r}143.00 \\
143.00 \\
4.747\end{array}$ \\
\hline \multirow[t]{3}{*}{$\begin{array}{l}\text { observed value } \\
\text { expected value }\end{array}$} & $\begin{array}{r}101.00 \\
88.31 \\
1.823\end{array}$ & $\begin{array}{l}43.00 \\
55.69 \\
2.892\end{array}$ & $\begin{array}{l}144.00 \\
141.00 \\
\quad 4.715\end{array}$ \\
\hline & 176.00 & 111.00 & $\begin{array}{r}287.00 \\
9.462\end{array}$ \\
\hline & 1 d.f. & $\mathrm{P}=.001$ & \\
\hline
\end{tabular}

On comparing the incidence of postoperative vomiting in patients receiving cyclizine with those in the control group, it is seen that cyclizine has a statistically significant effect on the incidence of vomiting $(P=.001)$.

TABLE II

Comparison between Pipamazine and Controls (Combined SERIES)

\begin{tabular}{lccc}
\hline & No vomiting & Vomiting & Total \\
\hline Controls & & & \\
observed value & 75.00 & 68.00 & 143.00 \\
expected value & 86.87 & 56.13 & 143.00 \\
& 1.621 & 2.510 & 4.131 \\
Pipamazine & & & \\
observed value & 103.00 & 47.00 & 150.00 \\
expected value & 91.13 & 58.87 & 150.00 \\
& 1.546 & 2.393 & 3.939 \\
& 178.00 & 115.00 & 293.00 \\
& & & 8.070 \\
\hline &
\end{tabular}


The pipamazine cases were examined in three ways.

(1) The first series of 83 patients receiving the larger dose, $P$ was .05 and just within the bounds of significance.

(2) The second series of 67 patients given the smaller second dose, $P$ was .03 , thus indicating slight improvement.

(3) The combined series of 150 patients. An analysis of Table II indicated that pipamazine showed a significant improvement over the control cases $(\mathrm{P}=.01)$.

TABLE III

Comparison of the RESUlts of TrImethobenzamide Administration with Controls (Combined Series)

\begin{tabular}{|c|c|c|c|}
\hline & No vomiting & Vomiting & Total \\
\hline \multicolumn{4}{|l|}{ Controls } \\
\hline observed values & $75 \quad 00$ & 6800 & 14300 \\
\hline expected values & $\begin{array}{rl}79 & 82 \\
0 & 291\end{array}$ & $\begin{array}{r}63.18 \\
0368\end{array}$ & $\begin{aligned} 14300 \\
.659\end{aligned}$ \\
\hline \multicolumn{4}{|c|}{ Trlmethobenzamide Hydrochloride } \\
\hline observed values & 11200 & 8000 & 19200 \\
\hline \multirow[t]{2}{*}{ expected values } & \begin{tabular}{r|l}
107 & 18 \\
0 & 217
\end{tabular} & $\begin{array}{rl}84 & 82 \\
0 & 274\end{array}$ & $\begin{array}{r}19200 \\
.491\end{array}$ \\
\hline & 18700 & 14800 & $\begin{array}{r}33500 \\
115\end{array}$ \\
\hline & I. d.f. & $=.30$ & \\
\hline
\end{tabular}

The trimethobenzamide group of cases was also studied in three ways (Table III).

(1) The first series, where the patients received 100-mg. doses only, show no improvement on the controls $(\mathrm{P}=.50)$.

(2) In the second series in which the dose was doubled, there is no significant improvement $(\mathrm{P}=.20)$.

(3) Table III presents the results of the combined cases: 192, consisting of 81 from the first group and 108 from the second series. There is no obviqus improvement as $P$ is still too high in value to be significant.

TABLE IS

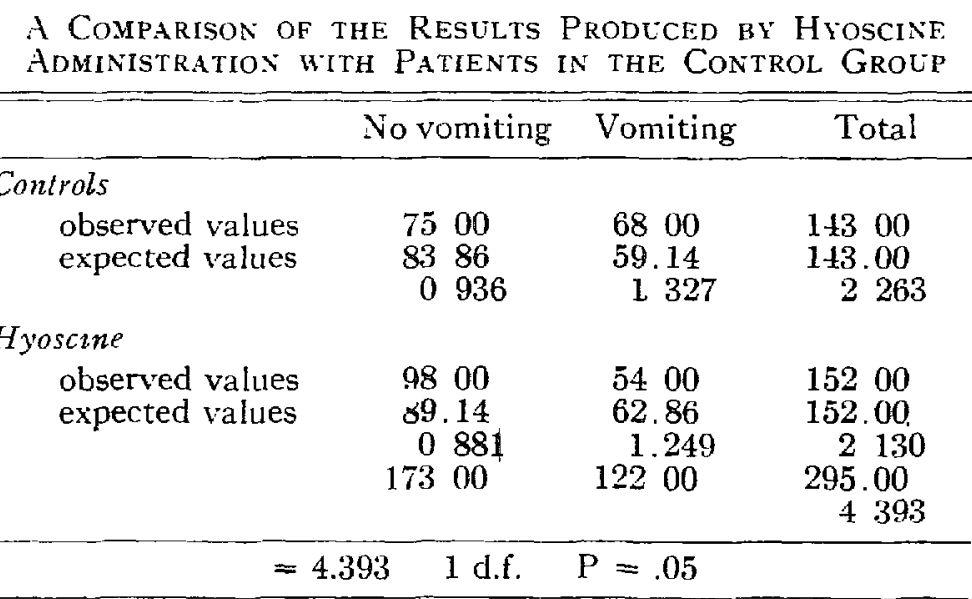


The results of the analysis in Table IV indicate the value of $P$ as .05 , which could be accepted as significant.

TABLE $V$

Comparison of Total Series

\begin{tabular}{cccc}
\hline & No vomiting & Vomiting & Total \\
\hline Controls & & & \\
observed value & 75.00 & 68.00 & 143.00 \\
expected value & 89.54 & 53.46 & 143.00 \\
& 2.361 & 3.955 & 6.316 \\
Cyclizine & & & \\
observed value & 101.00 & 43.00 & 144.00 \\
expected value & 90.16 & 53.84 & 144.00 \\
Pipamazine & 1.303 & 2.182 & 3.485 \\
observed value & 103.00 & 47.00 & 150.00 \\
expected value & 93.92 & 56.08 & 150.00 \\
Trimethobenzamide & 1.270 & 2.126 & 3.396 \\
observed value & 112.00 & 80.00 & 192.00 \\
expected value & 120.22 & 71.78 & 192.00 \\
& 0.562 & 0.941 & 1.503 \\
Hyoscine & & & \\
observed value & 98.00 & 54.00 & 152.00 \\
expected value & 95.16 & 56.84 & 152.00 \\
& 0.085 & 0.142 & .227 \\
& 489.00 & 292.00 & 781.00 \\
& & & 14.927 \\
& & & \\
\hline
\end{tabular}

The superiority of cyclizine is still evident in Table $V$, although pipamazine presents a definite decrease in the number of observed cases vomiting after operation.

\section{Discussion}

This study leads one to believe that cyclizine is the most effective anti-emetic of those studied in this series of patients. Chinn and his associates ${ }^{4}$ tested this drug for prevention of motion sickness in troops during transport (1952 and 1953), and he felt that it afforded significant protection. Previous experience with cyclizine showed that it had a synergistic effect when combined with a preoperative sedative, and the patients in an earlier series frequently arrived in the operating room too deeply sedated. Therefore, in this study the sedative dose was reduced when combining it with cyclizine. Belleville, Bross, and Holland ${ }^{5}$ showed that cyclizine did not increase the post-anaesthetic sleeping time, and that it did not produce significant hypotension. This writer feels that there is a higher incidence of postoperative vomiting in patients who become hypotensive during surgery.

Pipamazine also appeared to diminish the incidence of postoperative vomiting, although its efficiency was somewhat marred by the hypotension which occurred in some patients after the second dose which was given in the recovery room. 
There were 14 patients who had a sharp fall in blood pressure in the first series, that is, after the larger second dose, and there were 9 patients with hypotension in the second series. The degree of hypotension varied between $40-70 \mathrm{~mm}$. of $\mathrm{Hg}$, and occurred 10 to $15 \mathrm{~min}$. after the second administration. It was noticed that this complication arose mostly after minor operations, and it was presumed that the interval between the two doses was too short. However, there was one patient who responded unduly to the preoperative administration with a resulting hypotension, and it was considered necessary to postpone the operation because of the fall in blood pressure. It is interesting to notice that the reduction in dosage did not impair its ability to influence the incidence of vomiting favourably.

Trimethobenzamide does not present the same satisfactory picture, and in none of the three series does analysis show statistical significance. Since there were no side effects observed after the administration of trimethobenzamide and it did not appear to potentiate the sedatives given preoperatively, it may be that larger dosage would be more effective.

Hyoscine did show some anti-emetic effect in this study, although the results were not so appreciable as those obtained by Greene and Associates, ${ }^{6}$ who, after detailed investigations of a variety of drugs, expressed the opinion that of all drugs tested scopolamine hydrobromide is the drug that most closely fulfilis the criteria of the still undiscovered specific anti-emetic.

\section{SUMMARY}

The anti-emetic effect of cyclizine (Marzine ${ }^{(\circledR)}$ ), pipamazine, (Mornidine ${ }^{(\mathbb{B})}$, trimethobenzamide (Tigan ${ }^{\circledR}$ ), and hyoscine have been studied and compared in 781 surgical patients selected at random. The drugs were given intramuscularly with the preoperative sedative, and again 15 minutes after arrival in the recovery room. Analysis of the results showed that cyclizine was the most effective in reducing postoperative vomiting, but it was important to realize that it had a potentiating effect on the sedative drugs. Pipamazine also gave statistically significant results, but the incidence of hypotension occurring in the recovery room gave rise to some anxiety. A reduction in dosage minimized this side effect without impairing the anti-emetic effect of pipamazine. Trimethobenzamide did not appear to be effective in this study, and it is thought that since it does not give rise to side effects it could be employed in larger doses, and in this way might prove more effective. Hyoscine given preoperatively gave only fair protection in our series.

\section{ACKNOWLEDGMENTS}

This study would have been impossible without the co-operation of the surgeons and my colleagues in the anaesthetic department of the Women's College Hospital. Miss Robins, Research Assistant, kept the accurate records from which I derived the statistics. Mrs. Harms in the recovery room was most helpful in her care of the patients, administration of drugs, and observations. Dr. Hilda Roberts was most helpful in compiling the tables and gave invaluable assistance in the interpretation of the results. Cyclizine lactate was kindly supplied by 
Burroughs Wellcome \& Co. as Marzine ${ }^{\circledR}$, trimethobenzamide hydrochloride by Hoffman-LaRoche Ltd. as Tigan ${ }^{\circledR}$, and pipamazine by G. D. Searle Co. as Mornidine ${ }^{\circledR}$. We are also indebted to Burroughs Wellcome \& Co. for a contribution to the Research Fund. To all, I am most indebted and indeed grateful.

\section{RÉSUMÉ}

Chez 781 candidats à la chirurgie, pris au hasard, nous avons étudié et comparé les effets antiémétiques de la cyciizine (Marzine ${ }^{\circledR}$ ), de la pipamazine (Mornidine ${ }^{\circledR}$ ), de la triméthobenzamide (Tigan $\left.{ }^{\circledR}\right)$ et de l'hyoscine. Nous avons donné les médicaments par voie intra-musculaire en même temps que la sédation préopératoire et nous en avons répété l'injection quinze minutes après l'arrivée du malade à la salle de réveil. L'étude des résultats nous anène à la conclusion que la cyclizine a le mieux réussi à diminuer les vomissements post-opératoires, mais il est important de retenir qu'elle potentialise les effets sédatifs des médicaments. La pipamazine également a donné certains résultats mais les hypotensions observées dans la salle de réveil nous ont causé des inquiétudes. En diminuant les doses de la pipamazine, son pouvoir antiémétique n'a pas changé, mais ses effets secondaires ont été réduits. La trimethobenzamide, au cours de notre étude, ne s'est pas révélée efficace, mais, étant donné que-son emploi n'a donné lieu à aucun effet secondaire, il serait peut-être possible de l'employer à des doses plus fortes et d'obtenir ainsi de meilleurs résultats. L'hyoscine, employée en prémédication, au cours de cette étude, ne nous a fourni qu'une protection ordinaire.

\section{REFERENCES}

1. Dent, Sara J., Ramachandra, V., \& Stephen, C. R. Anesthesiology 16 (4): 564-572 (July, 1955).

2. Roberts, H. Canad. Anaesth. Soc. J. 7 (2): 119-125 (April, 1960).

3. Belleville, J. Weldon, Bross, Irwin D. J., \& Howland, Wm. S. Anesthesiology 20 (6): 761-766 (Nov.-Dec., 1959).

4. Chinn, H. I.; Handford, S. W.; Cone, I. E.; \& Smith, P. K. J. Pharm. Therap. 108:69 (May, 1953).

5. Belleville, J. Weldon, Bross, Irwin D. J., \& Howland, WM. S. Anesthesiology 21 (2): 186-193 (Mar.-April, 1960).

6. Greene, Barnett A. Brooklyn 36, New York. Personal communication 